Л.Р. Шостакович-Корецька, К.Ю. Литвин, О.О. Волікова, І.О. Губар, М.С. Суременко, О.А. Кушнєрова, О.В. Шевельова

\title{
РІВЕНЬ СИРОВАТКОВОГО БЕТА-2-МІКРОГЛОБУЛІНУ І ЙОГО ЗВ'ЯЗОК З ІМУНОЛОГІЧНИМИ ТА ГЕМАТОЛОГІЧНИМИ ПОКАЗНИКАМИ ПРИ ПРОГРЕСУВАННІ ВІЛ-ІНФЕКЦІї
}

\author{
Д3 «Дніпропетровська медична академія МОЗ України»
}

\begin{abstract}
Мета роботи - дослідити зв'язок між вмістом сироваткового бета-2-мікроглобуліну і основними гематологічними та імунологічними лабораторними показниками для визначення предикторних можливостей комплексного використання означених фракторів при ВІЛ-інфрекції.
\end{abstract}

Пацієнти і методи. Для дослідження були залучені 135 пацієнтів з ВІЛ-інфекцією віком від 20 до 56 років. Пацієнти з першою та другою клінічними стадіями хвороби склали 1-у групу $(n=30)$, з третьою стадією - 2-у групу $(n=28)$, з четвертою стадією - 3-ю групу дослідження (n=77). Група контролю - 15 здорових осіб відповідної статі і віку.

Визначення вмісту $\beta_{2}-$ МГ у сироватці крові проводилось за методом ІФА. Показники Т-лімфооцтів, Т-лімфроцитів-хелперів визначалися за допомогою проточної цитометрії. Гематологічний профріль досліджували за стандартною методикою, та включали аналіз вмісту гемоглобіну, лейкоцитів, тромбоцитів і ШОЕ в перифреричній крові пацієнтів з ВІЛ-інфрекцією.

Статистичну обробку результатів проводили за допомогою ліцензованого програмного продукту STATISTICA v.6.1®.

Результати. Встановлено статистично значиму відмінність як маркерів імунного статусу, так і показників гемограми, рівня тромбоцитів та ШОЕ у пацієнтів з різними клінічними стадіями ВІЛ-інфрекції при найбільшому відхиленні показників при четвертій стадії захворювання. Дослідження $\beta_{2}-$ МГ виявило стійку тенденцію до збільшення по мірі прогресування ВІЛ-інфекції - від 8,0 (6,3-9,0) нг/мл при 1-2-й стадії (1-а група) до 8, 75 (7,1-9,5) нг/мл при 3-й стадії (2-а група) $(p<0,05)$ і 9,0 $(8,2-9,5)$ нг/мл при 4-й клінічній стадії хвороби (3-я група дослідження) ( $p<0,001$, p<0,05). При 4-й клінічній стадії ВІЛ-інфекції (3-я група) рівень $\beta_{2}$-мікроглобуліну прямо корелював з ШОЕ
( $r s=0,42 ; p<0,001)$ та показником ВН PHК ВІЛ ( $r s=0,23$; $p<0,05)$. Зростання показника $\beta_{2}$-мікроглобуліну було пов'язане зі зниженням абсолютної кількості Т-лімфроцитів ( $r s=-0,40 ; p<0,01)$ і Т-лімфроцитівхелперів ( $r s=-0,39 ; p<0,01)$, загального числа лімфроцитів (rs=-0,43; $p<0,001)$ і відносної кількості T-лімфроцитів-хелперів у сироватці крові (rs=-0,36; $p<0,01)$.

Висновки. Підвищення вмісту $\beta_{2}$-мікроглобуліну відбувається паралельно зі зростанням ШОЕ та зменшенням кількості тромбоцитів й відповідає розвитку імуносупресії. Комплексне використання означених показників може бути основою предикторної моделі для визначення прогресування ВІЛ-інорекції в періоді між імунологічними дослідженнями.

Ключові слова: ВІЛ-інфекція, $\beta_{2}$-мікроглобулін, гематологічні показники, тромбоцити, ШОЕ.

Розвиток ВІЛ з моменту зараження у різних індивідуумів суттєво відрізняється за спектром: від дуже швидкого прогресування до довготривалої відсутності прогресу. Вважається, що психоемоційний стан ВІЛінфрікованої людини значно ускладнює об'єктивну оцінку варіабельності розвитку ВІЛ-інфекції на основі тільки клінічної симптоматики, що потребує пошуку неклінічних маркерів, які б доповнили різні клінічні параметри та дозволили точно оцінити стадію інфекції в індивідуума та прогнозувати її розвиток [1].

$€$ дані, які свідчать про роль маркеру імунної активації - бета-2-мікроглобуліну ( $\left.\beta_{2}-\mathrm{MГ}\right)$ у визначенні активності ВІЛ-інфекції: доведено, що підвищення цього маркеру пов'язане із прогресуванням ВІЛ та ризиком смерті [2-5]. Традиційними маркерами для моніторингу ВІЛ-інсекції в Україні, як і в інших країнах, є вірусне навантаження та кількість CD4. У той же час, визначення рівня $\beta_{2}$-мікроглобуліну довели його надійність та ефек- 
тивність як доступнішого прогностичного маркеру перебігу ВІЛ-інфекції [6-10].

Дані досліджень вказують також про такі зміни периферичної крові у пацієнтів з ВІЛ-інфекцією, як анемія, лейкопенія та тромбоцитопенія, які у більшості хворих асоціюються з прогресуванням недуги [11-14]. В літературі описана значна зворотна кореляція між вірусним навантаженням РНК ВІЛ та вказаними гематологічними змінами [15]. У той же час існують дослідження [12], які свідчать про низький відсоток пацієнтів з тромбоцитопенією, в яких кількість тромбоцитів зростала після покращення імунного статусу на тлі прийому антиретровірусної терапії, що потребує детальнішого вивчення.

Найбільш розповсюдженою серед пацієнтів з ВІЛінфрекцією $є$ анемія $[11,12]$. Тромбоцитопенію діагностують більш ніж у половини ВІЛ-інфікованих, і приблизно у $10 \%$ пацієнтів зниження числа тромбоцитів сигналізує про розвиток імуносупресії, маніфестацію СНІД та $€$ станом, що асоціюється з коротким виживанням [11]. В той же час, даних про можливості комплексного використання сироваткового $\beta_{2}$-мікроглобуліну разом 3 означеними гематологічними показниками як предикторів прогресування ВІЛ-інфекції недостатньо.

Мета роботи: дослідити зв'язок між вмістом сироваткового $\beta_{2}$-мікроглобуліну і основними гематологічними та імунологічними лабораторними показниками для визначення предикторних можливостей комплексного використання означених фракторів при ВІЛ-інфекції.

\section{Пацієнти і методи}

Для дослідження були залучені 135 пацієнтів з ВІЛінсрекцією віком від 20 до 56 років і розподілені на 3 групи, залежно від клінічної стадії недуги. Пацієнти з першою та другою клінічною стадією ВІЛ-інфрекції склали 1-у групу дослідження $(\mathrm{n}=30), 3$ третьою клінічною стадією - 2-у групу ( $\mathrm{n=28),} \mathrm{з} \mathrm{четвертою} \mathrm{клінічною} \mathrm{стадією} \mathrm{хвороби} \mathrm{-} \mathrm{3-ю}$ групу ( $\mathrm{n}=77)$.

До групи контролю увійшли 15 практично здорових осіб відповідної статі і віку.

Вміст $\beta_{2}$-МГ у сироватці крові визначали за методом ІФА зі стандартними тест-системами (виробництва США). Аналіз імунологічних показників: визначення кількості Т-лімсроцитів CD3+ (ТЛ), Т-лімфоцитів-хелперів CD3+CD4+ (ТЛХ) проводили за допомогою проточної цитометрії.

Дослідження гематологічного профрілю здійснювали за стандартною методикою, що включала аналіз вмісту гемоглобіну, лейкоцитів, тромбоцитів і ШОЕ в периферичній крові пацієнтів з ВІЛ.

Статистичну обробку результатів робили за допомогою ліцензійного програмного продукту STATISTICA v.6.1®. 3 урахуванням типу розподілу кількісних даних (критерій Колмогорова-Смирнова 3 поправкою Ліллієфорса) вико- ристовували параметричні або непараметричні характеристики і методи множинного порівняння: у випадку нормального розподілу - середню арифметичну (M) та ії стандартну похибку (m), критерій Ст'юдента з поправкою Бонфероні; при ненормальному розподілі - медіану (Me), інтерквартильний розмах (LQ - HQ), критерій Дункана. Проводився кореляційний аналіз з розрахунком коефіцієнтів рангової кореляції Спірмена $\left(\mathrm{r}_{\mathrm{s}}\right)$. Критичне значення рівня значимості (р) приймалося $<5 \%(p<0,05)$.

\section{Результати досліджень та їх обговорення}

Узагальнені результати досліджень основних лабораторних показників у групах пацієнтів з різними клінічними стадіями ВІЛ-інфекції наведені у таблиці 1.

Як видно, при попарному порівнянні лабораторних показників виявлено статистично значиму відмінність між маркерами імунного статусу та показниками гемограми у пацієнтів з різними клінічними стадіями ВІЛінорекції, з найбільшими відхиленнями показників при четвертій стадії захворювання. При порівнянні 1-ї (1-2 клінічні стадії ВІЛ-інфекції) та 2-ї (3 клінічна стадія) груп суттєву різницю відзначено лише у середніх рівнях відносної (\%) і абсолютної кількості Т-лімфроцитів-хелперів (ТЛХ), які при 3 стадії були достовірно менше на 16,7\% $(p<0,05)$ і 23,9\% ( $<<0,001)$ відповідно.

Порівняльний аналіз даних пацієнтів 3-ї групи (3 4 клінічною стадією ВІЛ- інсрекції) з 1-ю і 2-ю групами (1-2 та 3 клінічні стадії) довів суттєві відмінності більшості досліджуваних показників (табл. 1). Так, середня кількість тромбоцитів у пацієнтів 3-ї групи була зниженою в 1,2 разу ( $<<0,05)$, а показник ШОЕ - збільшеним в 3,1 $(p<0,001)$ і 2 рази $(p<0,01)$, ніж у пацієнтів 3 1-ї і 2-ї групи відповідно. Відносна та абсолютна кількість ТлХ у пацієнтів 3-ї групи (3 4 стадією ВІЛ-інфекції) була у 2,5 і 4,8 разу меншою за відповідні показники у пацієнтів 1-ї групи ( $p<0,001)$, і у 2,1 та 3,7 разу меншою, ніж у пацієнтів 2-ї групи $(p<0,001)$. У той же час, нами не виявлено суттєвих розбіжностей між показниками вмісту гемоглобіну та лейкоцитів у пацієнтів з різними клінічними стадіями ВІЛ-інфекції.

Суттєві відмінності між групами 1-2 і 3 (1-3 і 4 клінічні стадії ВІЛ-інфрекції) також відзначені відносно середніх показників загальної кількості лімфроцитів і ТЛ ( $<<0,001$ при усіх порівняннях з 3-ю групою). Середній показник вірусного навантаження РНК у хворих 3-ї групи $\left(\lg _{10} \mathrm{BH}\right.$ - 4,74 коп./мл) перевищував показники в інших групах більше, ніж на порядок - 3,02 коп./мл у 1-й групі $(p<0,01)$ і 3,49 коп./мл у 2-й групі $(p<0,05)$.

Дослідження маркерf імунної активації $\beta_{2}$-МГ у групах пацієнтів з різними клінічними стадіями ВІЛ-інфекції виявило значне перевищення відповідного показника у здорових осіб (у 8-9,5 разу; $p<0,001)$ та стійку тенденцію 


\section{ОРИГІНАЛЬНІ ДОСЛІДЖЕННЯ}

Таблиця 1

Середні рівні основних лабораторних показників у пацієнтів з різними клінічними стадіями ВІЛ-інфрекції

$(\mathrm{M} \pm \mathrm{m}$ або $\mathrm{Me}(\mathrm{LQ}-\mathrm{HQ}))$

\begin{tabular}{|c|c|c|c|c|}
\hline Показник & 1-a група $(n=30)$ & 2-a група $(n=28)$ & 3-я група (n=77) & Відмінності між групами \\
\hline Гемоглобін, г/л & $128,9 \pm 2,8$ & $126,1 \pm 3,6$ & $122,4 \pm 2,7$ & $\begin{array}{c}p_{1-2}=1,0 ; \\
p_{1-3}=0,470 ; p_{2-3}=1,0\end{array}$ \\
\hline Лейкоцити, Г/л & $5,21 \pm 0,25$ & $5,05 \pm 0,29$ & $4,48 \pm 0,20$ & $\begin{array}{c}p_{1-2}=1,0 ; \\
p_{1-3}=0,128 ; p_{2-3}=0,340\end{array}$ \\
\hline Тромбоцити, Г/л & $223,5 \pm 8,3$ & $229,5 \pm 12,8$ & $190,9 \pm 7,6$ & $\begin{array}{c}p_{1-2}=1,0 ; \\
p_{1-3}=0,050 ; p_{2-3}=0,017\end{array}$ \\
\hline ШОЕ, мм/год & $\begin{array}{c}7,0 \\
(5-12) \\
\end{array}$ & $\begin{array}{c}11,0 \\
(4-19)\end{array}$ & $\begin{array}{c}22,0 \\
(7-40)\end{array}$ & $\begin{array}{c}{ }^{*} p_{1-2}=0,130 ; \\
p_{1-3}<0,001 ; p_{2-3}=0,009\end{array}$ \\
\hline СD3+ТЛ (ТЛ), \% & $\begin{array}{c}79,0 \\
(74-83) \\
\end{array}$ & $\begin{array}{c}78,0 \\
(74-82) \\
\end{array}$ & $\begin{array}{c}73,0 \\
(52-81) \\
\end{array}$ & $\begin{array}{c}* p_{1-2}=0,744 ; \\
p_{1-3}=0,014 ; p_{2-3}=0,025\end{array}$ \\
\hline CD3+ТЛ, кл./мкл & $\begin{array}{c}1224 \\
(987-1554) \\
\end{array}$ & $\begin{array}{c}1156 \\
(997-1314)\end{array}$ & $\begin{array}{c}745 \\
(383-1133) \\
\end{array}$ & $\begin{array}{c}* p_{1-2}=0,325 ; \\
p_{1-3}<0,001 ; p_{2-3}<0,001\end{array}$ \\
\hline CD3+CD4+ ТЛ (ТЛХ), \% & $\begin{array}{c}24,0 \\
(21,1-35,0) \\
\end{array}$ & $\begin{array}{c}20,0 \\
(16,5-26,5) \\
\end{array}$ & $\begin{array}{c}9,5 \\
(5-16) \\
\end{array}$ & $\begin{array}{c}{ }^{*} \mathrm{p}_{1-2}=0,022 ; \\
\mathrm{p}_{1-3}<0,001 ; \mathrm{p}_{2-3}<0,001\end{array}$ \\
\hline CD3+CD4+ТЛ, кл./мкЛ & $\begin{array}{c}433,0 \\
(342-571) \\
\end{array}$ & $\begin{array}{c}329,5 \\
(255,5-393,5) \\
\end{array}$ & $\begin{array}{c}90 \\
(43-194) \\
\end{array}$ & $\begin{array}{c}* \mathrm{p}_{1-2}<0,001 ; \\
\mathrm{p}_{1-3}<0,001 ; \mathrm{p}_{2-3}<0,001\end{array}$ \\
\hline Лімсроцити, кл./мкл & $1737,1 \pm 122,6$ & $1579,8 \pm 88,3$ & $1089,7 \pm 74,4$ & $\begin{array}{c}p_{1-2}=0,925 ; \\
p_{1-3}<0,001 ; p_{2-3}<0,001\end{array}$ \\
\hline ВІЛ РНК (ВН), коп./мл & $\begin{array}{c}1362 \\
(75-12248) \\
\end{array}$ & $\begin{array}{c}3089 \\
(60-44676) \\
\end{array}$ & $\begin{array}{c}54954 \\
(178-260454) \\
\end{array}$ & $\begin{array}{c}* p_{1-2}=0,916 ; \\
p_{1-3}=0,083 ; p_{2-3}=0,084\end{array}$ \\
\hline $\lg _{10}$ ВН, коп./мл & $\begin{array}{c}3,02 \\
(1,88-4,09) \\
\end{array}$ & $\begin{array}{c}3,49 \\
(1,78-4,65) \\
\end{array}$ & $\begin{array}{c}4,74 \\
(2,25-5,42) \\
\end{array}$ & $\begin{array}{c}{ }^{*} p_{1-2}=0,587 ; \\
p_{1-3}=0,006 ; p_{2-3}=0,021\end{array}$ \\
\hline
\end{tabular}

Примітки: $p_{1-2}, p_{1-3}, p_{2-3}$ - рівень значимості відмінностей середніх показників у відповідних групах за критеріями Бонсрероні або Дункана $\left.{ }^{*}\right)$.

до збільшення рівня $\beta_{2}-\mathrm{MГ} \mathrm{по} \mathrm{мірі} \mathrm{прогресування} \mathrm{за-}$ хворювання - від 8,0 (6,3-9,0) нг/мл при 1-2 стадії (1-а група) до 8,75 (7,1-9,5) нг/мл при 3 стадії (2-а група) $(p<0,05)$ і 9,0 $(8,2-9,5)$ нг/мл при 4 клінічній стадії ВІЛінфекції (3-я група дослідження) ( $<<0,001$ і $p<0,05$ порівняно з попередніми групами) (табл. 2).

Таблиця 2

Вміст $\beta_{2}$-мікроглобуліну у сироватці крові пацієнтів з різними клінічними стадіями ВІЛ-інфекції

\begin{tabular}{|l|c|c|c|c|}
\hline \multirow{2}{*}{ Статистичний показник } & Здорові люди & \multicolumn{3}{|c|}{ ВІЛ-іноріковані } \\
\cline { 2 - 5 } & Контрольна група $(\mathrm{n}=15)$ & 1-а група $(\mathrm{n}=30)$ & 2-а група $(\mathrm{n}=28)$ & 3-я група $(\mathrm{n}=77)$ \\
\hline Мінімум - максимум, нг/мл & $0,1-1,2$ & $2,5-11,0$ & $4,8-12,5$ & $3,0-13,5$ \\
\hline Me (LQ - HQ), нг/мл & $1,0(0,8-1,1)$ & $8,0(6,3-9,0)$ & $8,75(7,1-9,5)$ & $9,5(8,45-10,8)$ \\
\hline Відмінності між групами & $\mathrm{p}<0,001$ з групами 1, 2, 3 & \multicolumn{2}{|c|}{$\mathrm{p}_{1-2}=0,045 ; \mathrm{p}_{1-3}<0,001 ; \mathrm{p}_{2-3}=0,015$} \\
\hline
\end{tabular}

Примітки: $\mathrm{p}_{1-2}, \mathrm{p}_{1-3}, \mathrm{p}_{2-3}$ - рівень значимості відмінностей середніх показників у відповідних групах за критерієм Дункана.

За результатами кореляційного аналізу у пацієнтів 1-ї та 2-ї групи з 1-3 клінічними стадіями ВІЛ-інфекції не виявлено достовірних зв'язків між рівнем $\beta_{2}$-МГ та імунологічними і гематологічними показниками. Водночас, при 4 клінічній стадії ВІЛ-інсрекції (3-я група) рівень цього білка прямо корелював з ШОЕ $\left(r_{s}=0,42\right.$; $p<0,001)$ та показником ВН РНК ВІЛ $\left(r_{s}=0,23 ; p<0,05\right)$. Зростання рівня $\beta_{2}-\mathrm{MГ}$ було пов'язане зі зниженням абсолютної кількості ТЛ ( $\left.r_{s}=-0,40 ; p<0,01\right)$ і ТЛX ( $r_{s}=-0,39$; $p<0,01)$, загального числа лімсроцитів $\left(r_{s}=-0,43 ; p<0,001\right)$ і відносної кількості ТЛХ у сироватці крові $\left(r_{s}=-0,36\right.$; $p<0,01)$. 
Таким чином, наведені дані свідчать про значну роль $\beta_{2}$-мікроглобуліну в патогенезі ВІЛ-інорекції. Особливо суттєвою визначена роль даного показника при прогресуванні хвороби та розвитку четвертої клінічної стадії ВІЛ-інфекції (СНІД). Достовірні прямі кореляційні зв'язки рівня $\beta_{2}$-мікроглобуліну з показниками вірусного навантаження і ШОЕ та зворотні зв'язки з ключовими імунологічними та гематологічними показниками дозволяють вважати цей білок маркером прогресування хвороби та використовувати його як достатньо до- ступний додатковий критерій прогнозування перебігу хвороби.

1. Підвищення вмісту $\beta_{2}$-мікроглобуліну відбувається паралельно зі зростанням ШОЕ та зменшенням кількості тромбоцитів і відповідає розвитку імуносупресії.

2. Комплексне використання означених показників може бути основою предикторної моделі для визначення прогресування ВІЛ-інфекції в періоді між імунологічними дослідженнями.

\section{Література}

1 Changes in plasma HIV-1 RNA and CD4+ lymphocyte counts and the risk of progression to AIDS / W. A. O'Brien, P. M. Hartigan, D. Martin [et al.] // New England Journal of Medicine. - 1996. - Vol. 334, N 7. - P. 426-431.

2. Halota W. Serum neopterin and beta2-microglobulin concentration as «prognostic markers» of AIDS / W. Halota, B. Jaruga, M. Pawłowska // Polski merkuriusz lekarski. - 2002. - Vol. 13, N 74. - P. 126-128.

3. The relationship between beta-2-microglobulin, CD4 lymphocyte count, AIDS and death in HIV-positive individuals / A. Mocroft, M. A. Johnson, C. A. Sabin [et al.] // Epidemiology and Infection. 1997. - Vol. 118, N 3. - P. 59.

4. Gupta S. M. Evaluation of beta2 microglobulin level as a marker to determine HIVIAIDS progression / S. M. Gupta, K. Ray, M. Bala // J. Commun. dis. - 2004. - Vol. 36, N 3. - P. 166-170.

5. Beta2 microglobulin as a surrogate marker for HIV infection: good correlation with CD4 counts / A. Wanchu, S. Arora, A. Bhatnagar [et al.] // Ind. J. Pathology \& Microbiology. - 2004. - Vol. 47, N 2. P. 298-301.

6. Serum beta2-microglobulin level increases in HIV infection: relation to seroconversion, CD4 T-cell fall and prognosis / B. Hofmann, Y. Wang, W. G. Cumberland [et al.] // AIDS. - 1990. - Vol. 4, N 3. P. 207-214.

7. Non-reliability of beta-2 microglobulin and neopterin as shortterm immunological markers of HIV progression / A. A. Onifade, G. J. Emeka, J. A. Olaniyi [et al.] // African J. Biomed. Res. - 2016. - Vol. 19, N 3. - P. 205-212.

8. Прогностическое значение ß2-микроглобулина и неоптерина на разних клинических стадиях ВИЧ-инфекции / О.А. Воликова, Л.Р. Шостакович-Корецка, Е.Ю. Литвин, Е.А. Кушнерова // Медичний фрорум. - 2014. - № 2. - С. 49-54.

\section{References}

1. O'brien, W.A., Hartigan, P.M., Martin, D., Esinhart, J., Hill, A., Benoit, S., ... \& Hamilton, J.D. (1996). Changes in plasma HIV-1 RNA and CD4+ lymphocyte counts and the risk of progression to AIDS. New England Journal of Medicine, 334 (7), 426-431.

2. Halota, W., Jaruga, B., \& Pawłowska, M. (2002). Serum neopterin and beta2-microglobulin concentration as «prognostic markers» of AIDS. Polski merkuriusz lekarski, 13 (74), 126-128.
9. Використання $\beta-2$ мікроглобуліну та неоптерину для прогнозування перебігу ВІЛ-інсекції / О.О. Волікова, Л.Р. ШостаковичКорецька, К.Ю. Литвин [та ін.] // Актуальні інсрекційні захворювання. Клініка, діагностика, лікування та профрілактика: зб. наук. праць Укр. військово-медичної академії. - Київ, 2015. - Вип. № 40. C. 381-387.

10. Прогностичне значення $\beta 2$-мікроглобуліну у ВІЛ-інфрікованих пацієнтів / О.О. Волікова, Л.Р. Шостакович-Корецька, К.Ю. Литвин [та ін.] // Фармакотерапія при інсрекційних захворюваннях: Матеріали наук.-практ. конфр. (6-7 квітня 2017, Київ). - Київ, 2017. - С. 25-26.

11. Surveillance for thrombocytopenia in persons infected with HIV: results from the multistate adult and adolescent spectrum of disease project / P. S. Sullivan, D. L. Hanson, S. Y. Chu [et al.] // JAIDS. - 1997. - Vol. 14, N 4. - P. 374-379.

12. Hematological profile of HIV patients in relation to immune status - a hospital-based cohort from Varanasi, North India / S. V. S. Attili, V. P. Singh, M. Rai [et al.] // Turk. J. Hematol. - 2008. - Vol. 25, N 1. - P. 13-19.

13. Profile of hematological abnormalities of Indian HIV infected individuals / B. Dikshit, A. Wanchu, R. K. Sachdeva [et al.] // BMC Hematology. - 2009. - Vol. 9, N 1. - P. 5.

14. Immunohematological reference ranges for adult Ethiopians / A. Tsegaye, T. Messele, T. Tilahun [et al.] // Clinical and Diagnostic Laboratory Immunology. - 1999. - Vol. 6, N 3. - P. 410-414.

15. HIV-associated hematologic disorders are correlated with plasma viral load and improve under highly active antiretroviral therapy / J. Servais, D. Nkoghe, J. C. Schmit [et al.] // JAIDS. - 2001. - Vol. 28, N 3. - P. 203-210.

3. Mocroft, A., Johnson, M.A., Sabin, C.A., Bofill, M., Janossy, G., \& Phillips, A.N. (1997). The relationship between beta-2-microglobulin, CD4 lymphocyte count, AIDS and death in HIV-positive individuals. Epidemiology \& Infection, 118 (3), 259-266.

4. Gupta, S. M., Ray, K., \& Bala, M. (2004). Evaluation of beta2 microglobulin level as a marker to determine HIVIAIDS progression. J. Commun. Dis., 36 (3), 166-170. 
5. Wanchu, A., Arora, S., Bhatnagar, A., Sud, A., Bambery, P., \& Singh, S. (2004). Beta2 microglobulin as a surrogate marker for HIV infection: good correlation with CD4 counts. Ind. J. Pathology \& Microbiology, 47 (2), 298-301.

6. Hofmann, B., Wang, Y., Cumberland, W.G., Detels, R., Bozorgmehri, M., \& Fahey, J.L. (1990). Serum beta2-microglobulin level increases in HIV infection: relation to seroconversion, CD4 T-cell fall and prognosis. AIDS, 4 (3), 207-214.

7. Onifade, A. A., Emeka, G. J., Olaniyi, J. A., Adeyanju, A. S., Ojerinde, A. O., \& Aiku, A. O. (2016). Non-reliability of beta-2 microglobulin and neopterin as short-term immunological markers of HIV progression. African J. Biomed. Res., 19 (3), 205-212.

8. Volikova, O.A., Shostakovich-Koretskaya, L.R., Litvin, E.Yu., \& Kushnerova, E.A. (2014). Prognosticheskoe znachenie $\beta 2$ mikroglobulina i neopterina na raznikh klinicheskikh stadiyakh VIChinfektsii [Prognostic value of $\beta 2$-microglobulin and neopterin at differen clinical stages of HIV infection]. Medychnyi forum [Medical Forum], 2, 49-54 [in Russian].

9. Volikova, O.A., Shostakovych-Koretska, L.R., Lytvyn, E.Yu., Kushnerova, E.A., Kriachkova, L.V., \& Marhitich, I.M. (2014). Vykorystannia $\beta-2$ mikrohlobulinu ta neopterynu dlia prohnozuvannia perebihu VIL-infektsii [ $\beta$-2 microglobulin and neopterin are used to predict the course of HIV infection]. Aktualni infektsiini zakhvoriuvannia. Klinika, diahnostyka, likuvannia ta profilaktyka: zbirnyk naukovykh practs Ukrainskoi viiskovo-medychnoi akademii [Acute Infectious Diseases. Clinic, Diagnostics, Treatment and Prevention. Collection of Scientific Works of the Ukrainian Military Medical Academy], 40, 381-387 [in Ukrainian].
10. Volikova, O.A., Shostakovych-Koretska, L.R., Lytvyn, E.Yu., Kushnerova, E.A., Kriachkova, L.V., Marhitich, I.M. ... \& Symonova, N.V. (2017). Prohnostychne znachennia $\beta 2$-mikrohlobulinu u VIL infikovanykh patsiientiv [Prognostic value of $\beta 2$-microglobulin in HIVinfected patients]. Farmakoterapiia pry infektsiinykh zakhvoriuvanniakh: Materialy naukovo-praktychnoi konferentsii [Pharmacotherapy for infectious diseases. Proceedings of the Conference]. Kyiv, April 6-7. (p. 25-26) [in Ukrainian].

11. Sullivan, P.S., Hanson, D.L., Chu, S.Y., Jones, J.L., Ciesielski, C.A., \& Adult/Adolescent Spectrum of Disease Group. (1997). Surveillance for thrombocytopenia in persons infected with HIV: results from the multistate Adult and Adolescent Spectrum of Disease Project. JAIDS, 14(4), 374-379.

12. Attili, S. V. S., Singh, V. P., Rai, M., Varma, D. V., Gulati, A. K., \& Sundar, S. (2008). Hematological profile of HIV patients in relation to immune status - a hospital-based cohort from Varanasi, North India. Turk. J. Hematol, 25 (1), 13-19.

13. Dikshit, B., Wanchu, A., Sachdeva, R. K., Sharma, A., \& Das, R. (2009). Profile of hematological abnormalities of Indian HIV infected individuals. BMC Hematology, 9 (1), 5.

14. Tsegaye, A., Messele, T., Tilahun, T., Hailu, E., Sahlu, T., Doorly, R. ... \& de Wit, T. F. R. (1999). Immunohematological reference ranges for adult Ethiopians. Clinical and Diagnostic Laboratory Immunology, 6 (3), 410-414

15. Servais, J., Nkoghe, D., Schmit, J. C., Arendt, V., Robert, I., Staub, T. ... \& Hemmer, R. (2001). HIV-associated hematologic disorders are correlated with plasma viral load and improve under highly active antiretroviral therapy. JAIDS, 28 (3), 203-210.

\section{SERUM LEVELS OF $\beta$-2 MICROGLOBULIN AND ITS RELATIONSHIP TO IMMUNOLOGICAL AND HEMATOLOGICAL PARAMETERS IN THE PROGRESSION OF HIV-INFECTION}

L.R. Shostakovych-Koretska, K.Yu. Lytvyn, O.O. Volikova, I.O. Hubar, M.S. Suremenko, O.A. Kushnierova, O.V. Sheveliova

Dnipropetrovsk Medical Academy of Health Ministry of Ukraine SUMMARY. The aim of the work - to investigate the relationship between the levels of serum beta-2-microglobulin (B2-MG) and the basic hematological and immunological laboratory parameters in order to determine the predictive potential of the complex use of these factors in HIV infection.

Patients and methods. 135 HIV-infected patients aged 20 to 56 years were involved in the study. Patients were categorized into three groups with the first and second clinical stage of HIV - group 1 (n=30), with the third stage - group 2 ( $n=28)$, the fourth stage - group 3 ( $n=77)$. The control group comprised 15 practically healthy persons of the corresponding sex and age. The levels of B2-MG in serum was determined by ELISA.
T-lymphocytes, T-helper (TH) cells were determined using Flow cytometry analysis. The examination of the hematological profile was carried out according to the standard method and included an analysis of the content of hemoglobin, leukocytes, platelets and ESR.

Statistical processing of the results was performed using the STATISTICA v.6.1® licensed software product.

Results. We established a statistically significant difference as markers of immune status and hemograms: platelet and ESR levels in patients with different clinical stages of HIV infection with the greatest deviation of the indicators in the fourth stage of the disease. The study of B2-MG revealed a steady tendency to increase as HIV progression ranged from $8.0(6.3-9.0) \mathrm{ng} / \mathrm{ml}$ at 1-2 stages (first group) to $8.75(7.1-9.5) \mathrm{ng} / \mathrm{ml}$ at stage 3 (group 2) $(p<0.05)$ and $9.0(8.2-9.5) \mathrm{ng} / \mathrm{ml}$ at 4 clinical stages of HIV (group 3) $(p<0.001, p<0.05)$.

At 4 clinical stages of HIV infection (group 3), the beta2-microglobulin level correlated directly with the ESR ( $r s=0.42 ; p<0.001)$ and the indicator of HBV RNA of HIV $(r s=0.23 ; p<0.05)$. Growth of the beta-2-microglobulin index was associated with a decrease in the absolute number of T-lymphocytes $(r s=-0.40 ; p<0.01)$ and $T$ - 


\section{ОРИГІНАЛЬНІ ДОСЛІДЖЕННЯ}

lymphocyte helper cells ( $r s=-0.39 ; p<0.01)$ The number of lymphocytes ( $r s=-0,43 ; p<0.001)$ and the relative amount of helper T-lymphocytes in serum (rs=-0.36; $p<0.01$ ).

Conclusions. The increase in the beta-2-microglobulin content occurs in parallel with the growth of ESR and the decrease in platelet count and corresponds to the development of immunosuppression. Complex use of these indicators can serve as a basis for prediction of the model for determining the progression of HIV in the period between immunological studies.

Key words: HIV infection; beta-2-microglobulin; hematological parameters; platelets; ESR.

\section{Відомості про авторів:}

Шостакович-Корецька Людмила Романівна - професор, д. мед. н., завідувач кафредри інфекційних хвороб ДЗ «ДМА мО3 України»; shost3@gmail.com

Литвин Катерина Юріївна - доцент, к. мед. н., доцент кафедри інфекційних хвороб ДЗ «ДМА МОЗ України»; k-lytvyn@ukr.net

Волікова Ольга Олександрівна - асистент кафедри інфекційних хвороб дз «ДМА МОЗ України»; ovolja@ukr. net

Губар Ірина Олександрівна - доцент, к. мед. н., доцент кафедри інфекційних хвороб ДЗ «ДМА МОЗ України»; gub. iryna@gmail.com

Суременко Микола Степанович - доцент, к. мед. н., доцент кафедри інфекційних хвороб дЗ «ДМА МОЗ України»; ovolja@ukr.net

Кушнєрова Олена Анатоліївна - асистент кафедри інсрекційних хвороб ДЗ «ДМА МОЗ України»; kushnerovaea@ ukr.net

Шевельова Олена Володимирівна - асистент кафедри інфекційних хвороб дз «ДМА МОЗ України»; shev3007@ gmail.com

\section{Information about authors:}

Shostakovych-Koretska Lyudmyla - Professor, DMS, Head of the Department of Infectious Diseases, SE «Dnipropetrovsk medical academy of Health Ministry of Ukraine»; shost3@ gmail.com

Lytvyn Kateryna - Associate Professor, PhD, Associate Professor of the Department of Infectious Diseases, SE «Dnipropetrovsk medical academy of Health Ministry of Ukraine»; k-lytvyn@ukr.net

Volikova Olha - Assistant Professor of the Department of Infectious Diseases SE «Dnipropetrovsk medical academy of Health Ministry of Ukraine»; ovolja@ukr.net

Hubar Iryna - Associate Professor, PhD, Associate Professor of the Department of Infectious Diseases, SE «Dnipropetrovsk medical academy of Health Ministry of Ukraine»; gub.iryna@gmail.com

Suremenko Mykola -Associate Professor, PhD, Associate Professor of the Department of Infectious Diseases, SE «Dnipropetrovsk medical academy of Health Ministry of Ukraine»; ovolja@ukr.net

Kushnyerova Olena - Assistant Professor of the Department of Infectious Diseases SE «Dnipropetrovsk medical academy of Health Ministry of Ukraine»; kushnerovaea@ukr.net

Shevelyova Olena-Assistant Professor of the Department of Infectious Diseases SE «Dnipropetrovsk medical academy of Health Ministry of Ukraine»; shev3007@gmail.com

Конфрлікт інтересів: немає.

Authors have no conflict of interest to declare.

Отримано 13.07.2017 p. 